\title{
Virgibacillus salinus sp. nov., a moderately halophilic bacterium from sediment of a saline lake
}

Correspondence

M. C. Márquez

cmarquez@us.es

\author{
I. J. Carrasco, M. C. Márquez and A. Ventosa
}

Department of Microbiology and Parasitology, Faculty of Pharmacy, University of Sevilla, 41012 Sevilla, Spain

A novel, moderately halophilic, Gram-positive bacterium, designated strain $\mathrm{XH}-22^{\top}$, was isolated from sediment of a saline lake located near Xilinhot, Inner Mongolia Autonomous Region, China. Cells were rod-shaped, endospore-forming and motile. The isolate was able to grow in the presence of $3-20 \%(\mathrm{w} / \mathrm{v})$ total salts (optimum, $10 \%$, w/v), and at $15-40{ }^{\circ} \mathrm{C}$ (optimum, $37{ }^{\circ} \mathrm{C}$ ) and $\mathrm{pH}$ 6.0-10.0 (optimum, $\mathrm{pH}$ 7.5). Strain $\mathrm{XH}-22^{\top}$ had diaminopimelic acid in the cell-wall peptidoglycan, MK-7 as the predominant menaquinone, and anteiso- $\mathrm{C}_{15: 0}, \mathrm{C}_{16: 0}$ and iso- $\mathrm{C}_{14: 0}$ as major fatty acids. The polar lipids comprised diphosphatidylglycerol, phosphatidylglycerol, a glycolipid and two unidentified phospholipids. The DNA G $+\mathrm{C}$ content of strain $\mathrm{XH}-22^{\top}$ was $38.8 \mathrm{~mol} \%$. 16S rRNA gene sequence analysis revealed that the novel strain was affiliated with the genus Virgibacillus. Levels of $16 \mathrm{~S}$ rRNA gene sequence similarity between strain $\mathrm{XH}-22^{\top}$ and the type strains of recognized Virgibacillus species ranged from $97.6 \%$ (with Virgibacillus carmonensis) to $94.9 \%$ (with Virgibacillus koreensis). Levels of DNA-DNA relatedness between strain $\mathrm{XH}-22^{\top}$ and $V$. carmonensis DSM $14868^{\top}$ and Virgibacillus necropolis DSM $14866^{\top}$ were 32 and $28 \%$, respectively. Strain $\mathrm{XH}-22^{\top}$ could be differentiated from recognized Virgibacillus species based on phenotypic characteristics, chemotaxonomic differences, phylogenetic analysis and genotypic features. On the basis of these results, strain $\mathrm{XH}-22^{\top}$ is considered to represent a novel species of the genus Virgibacillus, for which the name Virgibacillus salinus sp. nov. is proposed. The type strain is $\mathrm{XH}-22^{\top}\left(=\mathrm{CCM} 7562^{\top}=\right.$ CECT $\left.7439^{\top}=\mathrm{DSM} 21756^{\top}\right)$.

The genus Virgibacillus was first proposed by Heyndrickx et al. (1998) based on data from amplified rRNA gene restriction analysis, fatty acid profiles, SDS-PAGE patterns of whole-cell proteins and phenotypic characterization; its description was later emended by Heyrman et al. (2003). At the time of writing, the genus comprised 14 recognized species, namely Virgibacillus pantothenticus (type species of the genus) (Heyndrickx et al., 1998), V. proomii (Heyndrickx et al., 1999), V. carmonensis, V. necropolis, $V$. marismortui, V. salexigens (Heyrman et al., 2003), V. halodenitrificans (Yoon et al., 2004), V. dokdonensis (Yoon et al., 2005), V. koreensis (Lee et al., 2006), V. olivae (Quesada et al., 2007), V. halophilus (An et al., 2007), V. chiguensis (Wang et al., 2008), V. kekensis (Chen et al., 2008) and V. salarius (Hua et al., 2008). Members of the genus are motile, Gram-positive or Gram-variable rods, endospore-forming, catalase-positive, have a cell wall containing peptidoglycan of the meso-diaminopimelic acid type and DNA $\mathrm{G}+\mathrm{C}$ contents ranging from 30.7 to 42.8 mol\% (Wang et al., 2008; Chen et al., 2008). During the course of a study of halophilic bacteria from a saline lake in China, a moderately halophilic, Gram-positive

The GenBank/EMBL/DDBJ accession number for the 16S rRNA gene sequence of strain $\mathrm{XH}-22^{\top}$ is $\mathrm{FM} 205010$. bacterium, designated strain $\mathrm{XH}-22^{\mathrm{T}}$, was isolated. Phenotypic and chemotaxonomic characterization, together with DNA-DNA hybridization data and phylogenetic analysis based on 16S rRNA gene sequences, showed that strain $\mathrm{XH}-22^{\mathrm{T}}$ was related to members of the genus Virgibacillus but represented a novel species.

Strain XH- $22^{\mathrm{T}}$ was isolated from a sediment sample from a saline lake located near Xilinhot, Inner Mongolia Autonomous Region, China $\left(\begin{array}{llllll}43^{\circ} & 55^{\prime} \mathrm{N} & 115^{\circ} & 37^{\prime} & \mathrm{E}\end{array}\right)$, according to the methodology described by Carrasco et al. (2007). No other strains with characteristics similar to that of the new isolate were found in this habitat. At the time of sampling, the water in the lake had a conductivity of $44.9 \mathrm{mS} \mathrm{cm}{ }^{-1}$, a temperature of $18{ }^{\circ} \mathrm{C}$ and a $\mathrm{pH}$ of 7.5. The medium used for isolation was HM medium (Ventosa et al., 1982). The composition of this medium was (w/v) $17.8 \% \mathrm{NaCl}, 0.1 \% \mathrm{MgSO}_{4} .7 \mathrm{H}_{2} \mathrm{O}, 0.036 \% \mathrm{CaCl}_{2} .2 \mathrm{H}_{2} \mathrm{O}$, $0.2 \% \mathrm{KCl}, \quad 0.006 \% \mathrm{NaHCO}_{3}, \quad 0.023 \% \mathrm{NaBr}$, trace $\mathrm{FeCl}_{3} .6 \mathrm{H}_{2} \mathrm{O}, 1.0 \%$ yeast extract (Difco), $0.5 \%$ proteose peptone no. 3 (Difco) and $0.1 \%$ glucose. The $\mathrm{pH}$ was adjusted to 7.2 with $1 \mathrm{M} \mathrm{KOH}$. When necessary, solid media were prepared by adding $2.0 \%(\mathrm{w} / \mathrm{v})$ Bacto-agar (Difco). Strain $\mathrm{XH}-22^{\mathrm{T}}$ was routinely cultured on the maintenance medium described by Ventosa et al. (1982) 
supplemented with $10 \%(\mathrm{w} / \mathrm{v})$ marine salts. The composition of this medium was (w/v) $8.1 \% \mathrm{NaCl}, 0.7 \% \mathrm{MgCl}_{2}$, $0.96 \% \quad \mathrm{MgSO}_{4}, \quad 0.036 \% \quad \mathrm{CaCl}_{2}, \quad 0.2 \% \mathrm{KCl}, \quad 0.006 \%$ $\mathrm{NaHCO}_{3}, 0.026 \% \mathrm{NaBr}, 1 \%$ yeast extract, $0.5 \%$ proteose peptone no. 3 and $0.1 \%$ glucose; this was solidified with $2.0 \%(\mathrm{w} / \mathrm{v})$ Bacto-agar. The $\mathrm{pH}$ was adjusted to 7.2 with $1 \mathrm{M} \mathrm{KOH}$. V. carmonensis DSM $14868^{\mathrm{T}}$ and $V$. necropolis DSM $14866^{\mathrm{T}}$ were obtained from the DSMZ, Braunschweig, Germany, and were cultivated on maintenance medium at $28{ }^{\circ} \mathrm{C}$.

In order to characterize strain $\mathrm{XH}-22^{\mathrm{T}}$ phenotypically, standard tests were performed. The Gram stain reaction was carried out by using the method described by Dussault (1955). For the determination of cellular morphology and motility, a culture of cells at exponential grown phase in liquid medium was examined by using phase-contrast light microscopy (BX41 microscope; Olympus). The morphology of colonies, their pigmentation and size were observed under optimal growth conditions on maintenance medium after $24 \mathrm{~h}$ incubation at $37^{\circ} \mathrm{C}$. Growth at different concentrations of salts was determined on maintenance medium at salt concentrations of $0,0.5,1,3,5,7.5,10,15$, 20,25 and $30 \%(\mathrm{w} / \mathrm{v})$. Growth at different $\mathrm{pH}(5,6,7,8,9$, 10 and 11$)$ and temperatures $(10,14,15,20,25,30,37,40$, 41,45 and $50{ }^{\circ} \mathrm{C}$ ) was determined on maintenance medium. Anaerobic growth was determined on maintenance medium by using an anaerobe jar and $\mathrm{H}_{2}$ and $\mathrm{CO}_{2}$ GasPaks (BBL) to generate anaerobic conditions. Catalase was assayed by addition of $3 \%(\mathrm{v} / \mathrm{v}) \mathrm{H}_{2} \mathrm{O}_{2}$ to culture plates. The oxidase reaction was performed on filter paper moistened with $1 \%(\mathrm{w} / \mathrm{v})$ aqueous solution of $N, N, N^{\prime}, N^{\prime}$ tetramethyl-p-phenylendiamine. $V$. carmonensis DSM $14868^{\mathrm{T}}$ was employed in these tests as a control. Sporulation was tested on solid maintenance medium, and on this medium without proteose peptone or glucose, and supplemented with $1 \mathrm{~g}$ yeast extract $1^{-1}$ (Difco) and $5 \mathrm{mg} \mathrm{MnSO}{ }_{4} 1^{-1}$ (Merck) (Mn-medium) by using different temperatures for cultivation. Utilization of various substrates as sole carbon and energy, or carbon, nitrogen and energy sources was determined as described by Ventosa et al. (1982). Carbohydrates were added at $0.2 \%(\mathrm{w} / \mathrm{v})$, organic acids at $0.1 \%(\mathrm{w} / \mathrm{v})$ and alcohols at $0.1 \%(\mathrm{w} / \mathrm{v})$. Antibiotic susceptibility was determined according to the conventional Kirby-Bauer method (Bauer et al., 1966) on maintenance medium. V. carmonensis DSM $14868^{\mathrm{T}}$ and $V$. necropolis DSM $14866^{\mathrm{T}}$ were employed in these tests as reference strains. Other tests detailed in Table 1 or included in the species description were carried out by using the methods of Ventosa et al. (1982), Quesada et al. (1984) and García et al. (1987). Unless indicated otherwise, the tests were carried out on maintenance medium at $37{ }^{\circ} \mathrm{C}$ in sealed containers.

Cells of strain XH- $22^{\mathrm{T}}$ were Gram-positive, approximately $0.9 \times 1.5-6.0 \mu \mathrm{m}$, occurring singly, in pairs or in short chains. Cells were motile and strictly aerobic. When grown for $24 \mathrm{~h}$ at $37{ }^{\circ} \mathrm{C}$ on maintenance medium, colonies were circular with entire margins, cream-pigmented and $1 \mathrm{~mm}$ in diameter. Spherical to ellipsoidal endospores were formed at subterminal or terminal positions in swollen sporangia after 4 days cultivation on Mn-medium at $28{ }^{\circ} \mathrm{C}$. The isolate was moderately halophilic, being able to grow in media containing 3-20\% (w/v) salts and optimally in media containing $10 \%(\mathrm{w} / \mathrm{v})$ salts. No growth was observed in the absence of $\mathrm{NaCl}$. Growth was observed at $15-40{ }^{\circ} \mathrm{C}$ and at $\mathrm{pH} 6.0-10.0$. Optimal growth conditions in maintenance medium were at $37{ }^{\circ} \mathrm{C}$ and $\mathrm{pH}$ 7.5. Other phenotypic features are included in the species description.

Genomic DNA from strain XH- $22^{\mathrm{T}}$ was prepared according to the method described by Marmur (1961). The 16S rRNA gene was amplified by PCR with forward primer 16F27 and reverse primer 16R1488. Direct sequence determination of the PCR-amplified DNA was carried out by using an automated DNA sequencer (model ABI 3130XL; Applied Biosystems). Identification of phylogenetic neighbours and calculation of pairwise $16 \mathrm{~S}$ rRNA gene sequence similarity values were achieved by using the EzTaxon server (http://www.eztaxon.org/; Chun et al., 2007). 16S rRNA gene sequence analysis was performed with the ARB software package (Ludwig et al., 2004). The $16 \mathrm{~S}$ rRNA gene sequence of strain $\mathrm{XH}-22^{\mathrm{T}}$ was aligned with published sequences of closely related bacteria. The alignment was confirmed and checked against both primary and secondary structures of the 16S rRNA molecule by using the alignment tool of the ARB software package. Phylogenetic trees were constructed by using the maximum-likelihood (Felsenstein, 1981), maximum-parsimony (Fitch, 1971) and neighbour-joining (Saitou \& Nei, 1987) algorithms integrated within the ARB software for phylogenetic inference. Confidence values of branches of the phylogenetic tree were determined by using bootstrap analyses (Felsenstein, 1985) based on 1000 resamplings. $16 \mathrm{~S}$ rRNA gene sequences used for phylogenetic comparisons were obtained from the GenBank database and their strain designations and accession numbers are shown in Fig. 1.

An almost-complete 16S rRNA gene sequence of strain $\mathrm{XH}-22^{\mathrm{T}}$ (1472 nt) was obtained and used for initial BLAST and EzTaxon searches in GenBank and for phylogenetic analysis. Comparative 16S rRNA gene sequence analysis revealed that strain $\mathrm{XH}-22^{\mathrm{T}}$ was affiliated most closely with the genus Virgibacillus. In the phylogenetic tree based on the neighbour-joining algorithm, strain $\mathrm{XH}-22^{\mathrm{T}}$ fell within the radiation of a cluster comprising Virgibacillus species, forming a cluster with the type strains of $V$. carmonensis and $V$. necropolis with a high level of bootstrap support $(88 \%)$ (Fig. 1). The relationships among strain XH-22 ${ }^{\mathrm{T}}$ and the type strains of $V$. carmonensis and $V$. necropolis were also maintained in trees based on the maximumlikelihood and maximum-parsimony algorithms (data not shown). Strain $\mathrm{XH}-22^{\mathrm{T}}$ exhibited levels of $16 \mathrm{~S}$ rRNA gene sequence similarity of 97.6 and $97.5 \%$ with $\mathrm{V}$. carmonensis LMG $20964^{\mathrm{T}}$ and $V$. necropolis LMG $19488^{\mathrm{T}}$, respectively, and values of between 96.9 and $94.9 \%$ with the type strains of other recognized Virgibacillus species. DNA-DNA 
Table 1. Differential characteristics between strain $\mathrm{XH}-22^{\top}$ and related Virgibacillus species

Taxa: 1, strain XH-22 ${ }^{\mathrm{T}}$ (Virgibacillus salinus sp. nov.); 2, V. carmonensis (data from Heyrman et al., 2003); 3, V. necropolis (Heyrman et al., 2003); 4, V. pantothenticus (Heyndrickx et al., 1998); 5, V. proomii (Heyndrickx et al., 1998); 6, V. salexigens (Garabito et al., 1997); 7, V. marismortui (Arahal et al., 1999, 2000; Heyrman et al., 2003); 8, V. halodenitrificans (Yoon et al., 2004); 9, V. olivae (Quesada et al., 2007); 10, V. dokdonensis (Yoon et al., 2005); 11, V. koreensis (Lee et al., 2006); 12, V. halophilus (An et al., 2007); 13, V. kekensis (Chen et al., 2008); 14, V. chiguensis (Wang et al., 2008); 15, V. salarius (Hua et al., 2008). +, Positive; -, negative; W, weakly positive; ND, no data available; v, variable.

\begin{tabular}{|c|c|c|c|c|c|c|c|c|c|c|c|c|c|c|c|}
\hline Characteristic & 1 & 2 & 3 & 4 & 5 & 6 & 7 & 8 & 9 & 10 & 11 & 12 & 13 & 14 & 15 \\
\hline Oxidase & - & $+^{*}$ & $+^{*}$ & $\mathrm{ND}$ & ND & + & + & + & + & + & + & + & + & $\mathrm{ND}$ & + \\
\hline $\begin{array}{l}\text { Colony } \\
\text { pigmentation }\end{array}$ & Cream & Pink & - & - & - & - & - & - & Yellow & - & - & Yellow & - & - & White \\
\hline Anaerobic growth & - & - & - & + & + & - & - & + & - & + & + & - & - & + & - \\
\hline $\begin{array}{l}\text { Temperature } \\
\text { range }\left({ }^{\circ} \mathrm{C}\right)\end{array}$ & $10-40$ & $10-40$ & $10-40$ & $15-50$ & $15-50$ & $15-45$ & $15-50$ & $10-45$ & $20-45$ & $15-50$ & $10-45$ & $5-45$ & $10-50$ & ND & $10-50$ \\
\hline $\begin{array}{l}\text { Optimum tem- } \\
\text { perature }\left({ }^{\circ} \mathrm{C}\right)\end{array}$ & 37 & $25-30$ & $25-35$ & 37 & 37 & 37 & 37 & 38 & 30 & ND & 25 & $\mathrm{ND}$ & 37 & ND & $30-35$ \\
\hline $\begin{array}{l}\text { Nitrate reduced } \\
\text { to nitrite }\end{array}$ & + & + & + & $\mathrm{V}$ & - & - & + & + & + & - & - & + & + & + & - \\
\hline \multicolumn{16}{|l|}{ Hydrolysis of: } \\
\hline Aesculin & + & $-{ }^{\star}$ & - & + & + & + & + & $\mathrm{V}$ & $\mathrm{v}$ & + & + & ND & - & + & + \\
\hline Casein & - & $-{ }^{*}$ & $-^{*}$ & + & + & + & + & - & $\mathrm{V}$ & + & $\mathrm{ND}$ & ND & - & + & + \\
\hline Gelatin & - & $+^{*}$ & $+^{\star}$ & + & $\mathrm{V}$ & + & + & + & + & + & - & $\mathrm{ND}$ & - & + & $\mathrm{w}$ \\
\hline \multicolumn{16}{|c|}{ Acid production from: } \\
\hline D-Galactose & + & - & - & - & + & - & - & + & - & + & - & $\mathrm{w}$ & - & + & - \\
\hline D-Glucose & + & - & $+^{*}$ & - & + & + & + & + & - & + & $\mathrm{w}$ & + & + & + & + \\
\hline D-Fructose & + & - & $+^{*}$ & - & + & + & + & $\mathrm{V}$ & + & + & + & + & - & + & + \\
\hline D-Mannitol & - & - & - & - & - & + & - & + & - & - & - & + & $\mathrm{W}$ & $\mathrm{w}$ & $\mathrm{w}$ \\
\hline D-Rhamnose & + & - & - & + & - & - & - & - & - & - & ND & - & $\mathrm{ND}$ & - & - \\
\hline Trehalose & + & - & $\mathrm{w}$ & + & + & - & - & + & $\mathrm{ND}$ & - & $\mathrm{w}$ & + & $\mathrm{w}$ & - & - \\
\hline $\begin{array}{l}\text { DNA G }+ \text { C } \\
\text { content }(\mathrm{mol} \%)\end{array}$ & 38.8 & 38.9 & 37.3 & $36.9-38.3$ & $36.8-37.0$ & $36.3-39.5$ & $39.0-42.8$ & $38.0-39.0$ & $30.7-33.4$ & 36.7 & 41.0 & 42.6 & 41.8 & 37.3 & 37.3 \\
\hline
\end{tabular}

${ }^{\star}$ Data from the present study.

hybridization was carried out to evaluate levels of genomic DNA-DNA relatedness between strain $\mathrm{XH}-22^{\mathrm{T}}$ and $V$. carmonensis DSM $14868^{\mathrm{T}}$ and V. necropolis DSM $14866^{\mathrm{T}}$, following the competition procedure of Johnson (1994) as described in detail by Márquez et al. (2007). The hybridization temperature used was $45.2{ }^{\circ} \mathrm{C}$, which was within the limit of validity for the filter method (De Ley \& Tijtgat, 1970) and the level of DNA-DNA relatedness was calculated according to Johnson (1994). Experiments were carried out in triplicate. Levels of DNA-DNA relatedness between strain XH-22 ${ }^{\mathrm{T}}$ and $V$. carmonensis DSM $14868^{\mathrm{T}}$ and $V$. necropolis DSM $14866^{\mathrm{T}}$ were 32 and $28 \%$, respectively. These values were clearly lower than the $70 \%$ cut-off generally accepted for species delineation and support the placement of strain $\mathrm{XH}-22^{\mathrm{T}}$ as representing a genotypically distinct species within the genus Virgibacillus (Wayne et al., 1987).

The $\mathrm{G}+\mathrm{C}$ content of the genomic DNA was determined from the midpoint value $\left(T_{\mathrm{m}}\right)$ of the thermal denaturation profile (Marmur \& Doty, 1962) by using the equation of Owen \& Hill (1979). The G+C content of the DNA of strain $\mathrm{XH}-22^{\mathrm{T}}$ was $38.8 \mathrm{~mol} \%$. This is within the range of values described for species of the genus Virgibacillus, and is similar to those described for the type strains of $V$. carmonensis (38.9 mol\%; Heyrman et al., 2003) and V. necropolis (37.3 mol\%; Heyrman et al., 2003) (Table 1).

Analysis of the cell-wall peptidoglycan, quinones and polar lipids of strain $\mathrm{XH}-22^{\mathrm{T}}$ was carried out by the Identification Service of the DSMZ and Dr B. J. Tindall, DSMZ, Braunschweig, Germany. Cell biomass for these analyses was obtained by cultivation on maintenance medium at $37{ }^{\circ} \mathrm{C}$. Strain $\mathrm{XH}-22^{\mathrm{T}}$ contained a cell-wall peptidoglycan based on meso-diaminopimelic acid. MK-7 $(88 \%)$ was the predominant menaquinone, as reported for recognized species of the genus Virgibacillus; however, strain XH-22 ${ }^{\mathrm{T}}$ had MK-6 (3\%), MK-5 (3\%) and an unidentified respiratory quinone (about $6 \%$ ) present in minor amounts, whereas $V$. carmonensis DSM $14868^{\mathrm{T}}$ and $V$. necropolis DSM $14866^{\mathrm{T}}$ had MK-6 and MK-8 as minor components (Heyrman et al., 2003). The polar lipid profile of strain $\mathrm{XH}-22^{\mathrm{T}}$ comprised diphosphatidylglycerol, phosphatidylglycerol, a glycolipid and two phospholipids of 


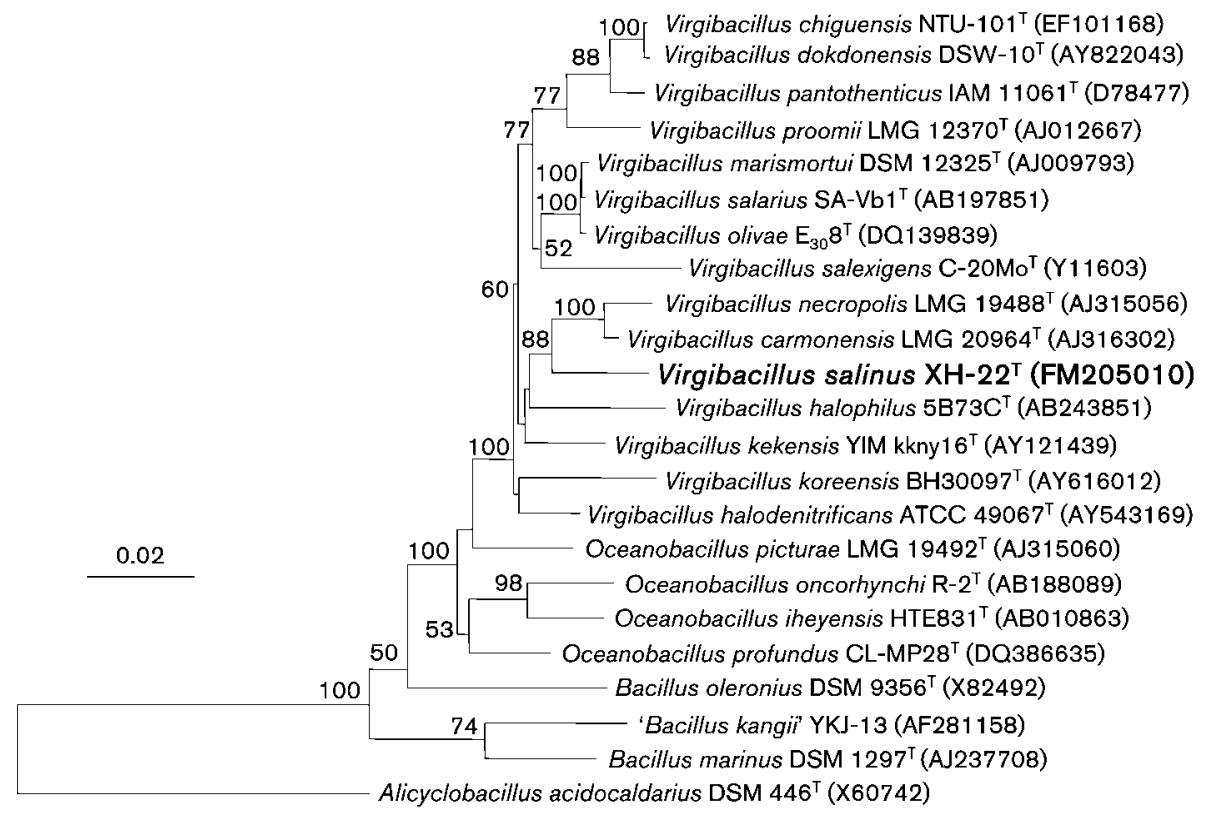

Fig. 1. Neighbour-joining tree, based on $16 \mathrm{~S}$ rRNA gene sequence comparisons, showing the relationship between strain $\mathrm{XH}-$ $22^{T}$ and related species. Accession numbers of the sequences used in this study are shown in parentheses after the strain designation. Alicyclobacillus acidocaldarius DSM $446^{\top}$ was used as an outgroup. Bootstrap values of $\geqslant 50 \%$ are shown at nodes. Bar, 0.02 substitutions per nucleotide position.

unknown structure. The presence of diphosphatidylglycerol and phosphatidylglycerol as major polar lipids is a common characteristic of Virgibacillus species (Heyrman et al., 2003; Wang et al., 2008) but the presence of a glycolipid has not previously been reported for members of the genus.

Fatty acid analysis was performed by using the MIDI system (Microbial Identification System) and was carried out by the Identification, Characterization and Molecular Typing Service of the BCCM/LMG bacterial collection. Cells were cultured on maintenance medium at $37^{\circ} \mathrm{C}$ for $24 \mathrm{~h}$. The predominant fatty acids of strain $\mathrm{XH}-22^{\mathrm{T}}$ were anteiso- $\mathrm{C}_{15: 0}(32.0 \%), \mathrm{C}_{16: 0}(20.5 \%)$ and iso- $\mathrm{C}_{14: 0}$ $(17.1 \%)$. The detailed fatty acid profile was similar to those of recognized species of the genus Virgibacillus, although there were differences in the proportion of some fatty acids that might have been caused by different cultivation conditions (Table 2).

Strain $\mathrm{XH}-22^{\mathrm{T}}$ showed some differences in phenotypic characteristics from recognized Virgibacillus species (Table 1). In particular, strain $\mathrm{XH}-22^{\mathrm{T}}$ can be distinguished clearly from $V$. carmonensis, its nearest phylogenetic neighbour, based on differences in the oxidase reaction, colony pigmentation, optimum temperature for growth and acid production from various substrates (Table 1). The phylogenetic distinctiveness and DNA-DNA relatedness data clearly suggest that strain $\mathrm{XH}-22^{\mathrm{T}}$ represents a species that is distinct from recognized Virgibacillus species
(Wayne et al., 1987; Stackebrandt \& Goebel, 1994). Therefore, on the basis of the data presented, strain $\mathrm{XH}-$ $22^{\mathrm{T}}$ should be classified in the genus Virgibacillus as representing a novel species, for which the name Virgibacillus salinus sp. nov. is proposed.

Table 2. Cellular fatty acid profiles of strain $\mathrm{XH}-22^{\top}$ and the type strains of $V$. carmonensis and $V$. necropolis

Strains: 1, XH-22 ${ }^{\mathrm{T}}$ (Virgibacillus salinus sp. nov.); 2, V. carmonensis DSM $14868^{\mathrm{T}}$ (data from Heyrman et al., 2003); 3, V. necropolis DSM $14866^{\mathrm{T}}$ (Heyrman et al., 2003). Values are percentages of total fatty acids; values $<1 \%$ are not shown.

\begin{tabular}{|c|c|c|c|}
\hline Fatty acid & 1 & 2 & 3 \\
\hline \multicolumn{4}{|l|}{ Straight chain } \\
\hline $\mathrm{C}_{14: 0}$ & 4.2 & - & - \\
\hline$C_{16: 0}$ & 20.5 & 1.1 & 1.3 \\
\hline \multicolumn{4}{|l|}{ Branched } \\
\hline iso- $\mathrm{C}_{14: 0}$ & 17.1 & 3.5 & 2.9 \\
\hline iso- $\mathrm{C}_{15: 0}$ & 9.4 & 4.5 & 4.2 \\
\hline anteiso- $\mathrm{C}_{15: 0}$ & 32.0 & 65.5 & 71.5 \\
\hline iso- $\mathrm{C}_{16: 0}$ & 3.6 & 3.6 & 3.6 \\
\hline anteiso- $\mathrm{C}_{17: 0}$ & 1.7 & 9.4 & 9.3 \\
\hline \multicolumn{4}{|l|}{ Unsaturated } \\
\hline $\mathrm{C}_{16: 1} \omega 7 c$ alcohol & 1.4 & 5.0 & 2.4 \\
\hline $\mathrm{C}_{16: 1} \omega 11 c$ & 6.7 & 1.0 & 1.0 \\
\hline
\end{tabular}




\section{Description of Virgibacillus salinus sp. nov.}

Virgibacillus salinus (sa.li'nus. L. masc. adj. salinus of or belonging to salt).

Cells are Gram-positive, $0.9 \times 1.5-6.0 \mu \mathrm{m}$, occurring singly, in pairs or in short chains. Cells are motile. Spherical to ellipsoidal endospores are produced at subterminal or terminal positions in swollen sporangia after 4 days cultivation on Mn-medium at $28{ }^{\circ} \mathrm{C}$. Colonies are circular, opaque, entire, $1 \mathrm{~mm}$ in diameter and cream-pigmented on HM medium supplemented with $10 \%$ salts after $24 \mathrm{~h}$ cultivation at $37{ }^{\circ} \mathrm{C}$. Moderately halophilic; is able to grow over a wide range of salt concentrations (3-20\%, w/v), with optimal growth at $10 \%(\mathrm{w} / \mathrm{v})$ salts. No growth occurs in the absence of $\mathrm{NaCl}$. Grows at $15-40{ }^{\circ} \mathrm{C}$ (optimum, $37{ }^{\circ} \mathrm{C}$ ) and pH 6.0-10.0 (optimum, pH 7.5). Strictly aerobic. Catalasepositive and oxidase-negative. Nitrate is reduced to nitrite. Acid is produced from arabinose, D-fructose, galactose, Dglucose, D-lactose, maltose, sucrose, trehalose and D-xylose, but not from glycerol or D-mannitol. Casein, gelatin and starch are not hydrolysed, but Tween 80 and aesculin are hydrolysed. $\mathrm{H}_{2} \mathrm{~S}$ is not produced. Indole, methyl red, Simmons citrate, Voges-Proskauer, phosphatase, arginine dihydrolase, and lysine and ornithine decarboxylase tests are negative. The following compounds are utilized as sole carbon and energy sources: D-arabinose, D-galactose, Dlactose, maltose, sucrose, D-xylose, ethanol, D-mannitol, xylitol, citrate, formate and propionate. The following compounds are not utilized: starch, cellobiose, D-fructose, L-fucose, D-glucose, D-mannose, melibiose, raffinose, Dribose, trehalose, butanol, dulcitol, glycerol, myo-inositol, propanol, D-sorbitol, methanol, acetate, benzoate, fumarate, succinate and valerate. The following compounds are used as sole carbon, nitrogen and energy sources: L-alanine, Larginine, L-methionine, L-serine, L-threonine and tryptophan. The following compounds are not used: L-cysteine, phenylalanine, glutamic acid and L-ornithine. Susceptible to ampicillin $(10 \mu \mathrm{g})$, bacitracin $(10 \mathrm{U})$, chloramphenicol $(30 \mu \mathrm{g})$, erythromycin $(15 \mu \mathrm{g})$ and novobiocin $(30 \mu \mathrm{g})$. Resistant to gentamicin $(10 \mu \mathrm{g})$, kanamycin $(30 \mu \mathrm{g})$, nalidixic acid $(30 \mu \mathrm{g})$, neomycin $(10 \mu \mathrm{g})$, penicillin (10 U) and rifampicin $(30 \mu \mathrm{g})$. The peptidoglycan type is $\mathrm{A} 1 \gamma$, with meso-diaminopimelic acid as the diagnostic diamino acid. MK-7 is the predominant menaquinone, with MK-6, MK-5 and an unidentified respiratory quinone present in minor amounts. The predominant cellular fatty acids are anteiso$\mathrm{C}_{15: 0}, \mathrm{C}_{16: 0}$ and iso- $\mathrm{C}_{14: 0}$; iso- $\mathrm{C}_{15: 0}, \mathrm{C}_{16: 1} \omega 11 c, \mathrm{C}_{14: 0}$, iso$\mathrm{C}_{16: 0}$, anteiso- $\mathrm{C}_{17: 0}, \mathrm{C}_{18: 0}, \mathrm{C}_{16: 1} \omega 7 c$ alcohol, iso- $\mathrm{C}_{17: 0}$, anteiso- $\mathrm{C}_{13: 0}$ and iso- $\mathrm{C}_{13: 0}$ are present as minor components. Polar lipids are diphosphatidylglycerol, phosphatidylglycerol, a glycolipid and two unidentified phospholipids. The DNA G + C content of the type strain is $38.8 \mathrm{~mol} \%$ $\left(T_{\mathrm{m}}\right)$. The description of this species is based upon study of a single strain.

The type strain, $\mathrm{XH}-22^{\mathrm{T}} \quad\left(=\mathrm{CCM} \quad 7562^{\mathrm{T}}=\mathrm{CECT}\right.$ $7439^{\mathrm{T}}=$ DSM $21756^{\mathrm{T}}$ ), was isolated from sediment of a salt lake near Xilinhot in Inner Mongolia, China.

\section{Acknowledgements}

This study was supported by grants from the Spanish Ministerio de Educación y Ciencia (BIO2006-06927) and Junta de Andalucía (PO6CVI-01829).

\section{References}

An, S.-Y., Asahara, M., Goto, K., Kasai, H. \& Yokota, A. (2007). Virgibacillus halophilus sp. nov., spore-forming bacteria isolated from soil in Japan. Int J Syst Evol Microbiol 57, 1607-1611.

Arahal, D. R., Márquez, M. C., Volcani, B. E., Schleifer, K. H. \& Ventosa, A. (1999). Bacillus marismortui sp. nov., a new moderately halophilic species from the Dead Sea. Int J Syst Bacteriol 49, 15011503.

Arahal, D. R., Márquez, M. C., Volcani, B. E., Schleifer, K. H. \& Ventosa, A. (2000). Reclassification of Bacillus marismortui as Salibacillus marismortui comb. nov. Int J Syst Evol Microbiol 50, 1501-1503.

Bauer, A. W., Kirby, W. M. M., Sherris, J. C. \& Turck, M. (1966). Antibiotic susceptibility testing by a standardized single disk method. Am J Clin Pathol 45, 493-496.

Carrasco, I. J., Márquez, M. C., Xue, Y., Ma, Y., Cowan, D. A., Jones, B. J., Grant, W. D. \& Ventosa, A. (2007). Salsuginibacillus kocurii gen. nov., sp. nov., a moderately halophilic bacterium from soda-lake sediment. Int J Syst Evol Microbiol 57, 2381-2386.

Chen, Y.-G., Cui, X.-L., Fritze, D., Chai, L.-H., Schumann, P., Wen, M.-L., Wang, Y.-X., Xu, L.-H. \& Jiang, C.-L. (2008). Virgibacillus kekensis sp. nov., a moderately halophilic bacterium isolated from a salt lake in China. Int J Syst Evol Microbiol 58, 647-653.

Chun, J., Lee, J.-H., Jung, Y., Kim, M., Kim, S., Kim, B. K. \& Lim, Y.-W. (2007). EzTaxon: a web-based tool for the identification of prokaryotes based on $16 \mathrm{~S}$ ribosomal RNA gene sequences. Int J Syst Evol Microbiol 57, 2259-2261.

De Ley, J. \& Tijtgat, R. (1970). Evaluation of membrane filter methods for DNA-DNA hybridization. Antonie van Leeuwenhoek 36, 461-474.

Dussault, H. P. (1955). An improved technique for staining red halophilic bacteria. J Bacteriol 70, 484-485.

Felsenstein, J. (1981). Evolutionary trees from DNA sequences: a maximum likelihood approach. J Mol Evol 17, 368-376.

Felsenstein, J. (1985). Confidence limits on phylogenies: an approach using the bootstrap. Evolution 39, 783-791.

Fitch, W. M. (1971). Toward defining the course of evolution: minimum change for a specific tree topology. Syst Zool 20, 406-416.

Garabito, M. J., Arahal, D. R., Mellado, E., Márquez, M.-C. \& Ventosa, A. (1997). Bacillus salexigens sp. nov., a new moderately halophilic Bacillus species. Int J Syst Bacteriol 47, 735-741.

Garcia, M. T., Ventosa, A., Ruiz-Berraquero, F. \& Kocur, M. (1987). Taxonomic study and amended description of Vibrio costicola. Int $J$ Syst Bacteriol 37, 251-256.

Heyndrickx, M., Lebbe, L., Kersters, K., De Vos, P., Forsyth, G. \& Logan, N. A. (1998). Virgibacillus: a new genus to accommodate Bacillus pantothenticus (Proom and Knight 1950). Emended description of Virgibacillus pantothenticus. Int J Syst Bacteriol 48, 99-106.

Heyndrickx, M., Lebbe, L., Kersters, K., Hoste, B., De Wachter, R., De Vos, P., Forsyth, G. \& Logan, N. A. (1999). Proposal of Virgibacillus promii sp. nov. and emended description of Virgibacillus pantothenticus (Proom and Knight 1950) Heyndrickx et al. 1998. Int J Syst Bacteriol 49, 1083-1090.

Heyrman, J., Logan, N. A., Busse, H.-J., Balcaen, A., Lebbe, L., Rodriguez-Díaz, M., Swings, J. \& De Vos, P. (2003). Virgibacillus 
carmonensis sp. nov., Virgibacillus necropolis sp. nov. and Virgibacillus picturae sp. nov., three novel species isolated from deteriorated mural paintings, transfer of the species of the genus Salibacillus to Virgibacillus, as Virgibacillus marismortui comb. nov. and Virgibacillus salexigens comb. nov., and emended description of the genus Virgibacillus. Int J Syst Evol Microbiol 53, 501-511.

Hua, N.-P., Hamza-Chaffai, A., Vreeland, R. H., Isoda, H. \& Naganumal, T. (2008). Virgibacillus salarius sp. nov., a halophilic bacterium isolated from a Saharan salt lake. Int J Syst Evol Microbiol 58, 2409-2414.

Johnson, J. L. (1994). Similarity analysis of DNAs. In Methods for General and Molecular Bacteriology, pp. 655-681. Edited by P. Gerhardt, R. G. E. Murray, W. A. Wood \& N. R. Krieg. Washington, DC: American Society for Microbiology.

Lee, J.-S., Lim, J.-M., Lee, K. C., Lee, J.-C., Park, Y.-H. \& Kim, C.-J. (2006). Virgibacillus koreensis sp. nov., a novel bacterium from a salt field, and transfer of Virgibacillus picturae to the genus Oceanobacillus as Oceanobacillus picturae comb. nov. with emended descriptions. Int J Syst Evol Microbiol 56, 251-257.

Ludwig, W., Strunk, O., Westram, R., Richter, L., Meier, H., Yadhukumar, X., Buchner, A., Lai, T., Steppi, S. \& other authors (2004). ARB: a software environment for sequence data. Nucleic Acids Res 32, 1363-1371.

Marmur, J. (1961). A procedure for the isolation of deoxyribonucleic acid from microorganisms. J Mol Biol 3, 208-218.

Marmur, J. \& Doty, P. (1962). Determination of the base composition of deoxyribonucleic acid from its thermal denaturation temperature. J Mol Biol 5, 109-118.

Márquez, M. C., Carrasco, I. J., Xue, Y., Ma, Y., Cowan, D. A., Jones, B. J., Grant, W. D. \& Ventosa, A. (2007). Aquisalimonas asiatica gen. nov., sp. nov., a moderately halophilic bacterium isolated from an alkaline, saline lake in Inner Mongolia, China. Int J Syst Evol Microbiol 57, 1137-1142.

Owen, R. J. \& Hill, L. R. (1979). The estimation of base compositions, base pairing and genome sizes of bacterial deoxyribonucleic acids. In Identification Methods for Microbiologists (Society for Applied
Bacteriology Technical Series no. 14), 2nd edn, pp. 277-296. Edited by F. A. Skinner \& D. W. Lovelock. London: Academic Press.

Quesada, E., Ventosa, A., Ruiz-Berraquero, F. \& RamosCormenzana, A. (1984). Deleya halophila, a new species of moderately halophilic bacteria. Int J Syst Bacteriol 34, 287-292.

Quesada, T., Aguilera, M., Morillo, J. A., Ramos-Cormenzana, A. \& Monteoliva-Sánchez, M. (2007). Virgibacillus olivae sp. nov., isolated from waste wash-water from processing of Spanish-style green olives. Int J Syst Evol Microbiol 57, 906-910.

Saitou, N. \& Nei, M. (1987). The neighbor-joining method: a new method for reconstructing phylogenetic trees. Mol Biol Evol 4, 406425.

Stackebrandt, E. \& Goebel, B. M. (1994). Taxonomic note: a place for DNA-DNA reassociation and $16 \mathrm{~S}$ rRNA sequence analysis in the present species definition in bacteriology. Int J Syst Bacteriol 44, 846849.

Ventosa, A., Quesada, E., Rodriguez-Valera, F., Ruiz-Berraquero, F. \& Ramos-Cormenzana, A. (1982). Numerical taxonomy of moderately halophilic Gram-negative rods. J Gen Microbiol 128, 1959-1968.

Wang, C.-Y., Chang, C.-C., Ng, C. C., Chen, T.-W. \& Shyu, Y.-T. (2008). Virgibacillus chiguensis sp. nov., a novel halophilic bacterium isolated from Chigu, a previously commercial saltern located in southern Taiwan. Int J Syst Evol Microbiol 58, 341-345.

Wayne, L. G., Brenner, D. J., Colwell, R. R., Grimont, P. A. D., Kandler, O., Krichevsky, M. I., Moore, L. H., Moore, W. E. C., Murray, R. G. E. \& other authors (1987). International Committee on Systematic Bacteriology. Report of the ad hoc committee on reconciliation of approaches to bacterial systematics. Int J Syst Bacteriol 37, 463-464.

Yoon, J.-H., Oh, T. K. \& Park, Y.-H. (2004). Transfer of Bacillus halodenitrificans Denariaz et al. 1989 to the genus Virgibacillus as Virgibacillus halodenitrificans comb. nov. Int J Syst Evol Microbiol 54, 2163-2167.

Yoon, J.-H., Kang, S. J., Lee, S. Y., Lee, M. H. \& Oh, T. K. (2005). Virgibacillus dokdonensis sp. nov., isolated from a Korean island, Dokdo, located at the edge of the East Sea in Korea. Int J Syst Evol Microbiol 55, 1833-1837. 